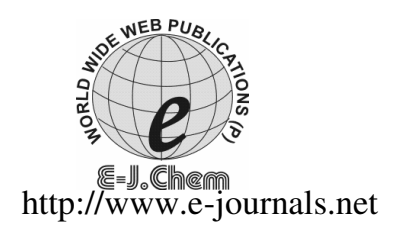

\title{
One-Pot Synthesis of Tetrasubstituted Imidazoles Catalyzed by Preyssler-Type Heteropoly Acid
}

\author{
ALI JAVID $^{\S^{*}}$, MAJID M. HERAVI ${ }^{\#}$, \\ F. F. BAMOHARRAM and MOHSEN NIKPOUR ${ }^{\S}$ \\ ${ }^{\S}$ Department of Chemistry, School of Sciences \\ Islamic Azad University, Ahvaz Branch, Ahvaz 6134968875, Iran \\ \#Department of Chemistry \\ Azzahra University, Vanak, Tehran, Iran \\ Department of Chemistry, School of Sciences \\ Islamic Azad University, Mashhad Branch, Mashhad, Iran \\ alijavids@yahoo.com
}

Received 27 June 2010; Accepted 2 September 2010

\begin{abstract}
A simple one-pot four-component synthetic method was reported for the preparation of tetrasubstituted imidazole derivatives from benzil, aromatic aldehydes, primary amines and ammonium acetate in the presence of Preyssler-type heteropoly acid catalyst. This method was proved to be ecobenign, easy work-up, convenient, relatively short reaction times and the products were isolated with high yields.
\end{abstract}

Keywords: Multi-component reactions (MCRs), One-pot synthesis, tetrasubstituted imidazoles, Preyssler catalyst, Heteropoly acid (HPA)

\section{Introduction}

Imidazole, at first, has been prepared by debus ${ }^{1}$ in 1858 . Over the century, imidazole derivatives have received significant attention due to their synthesis, reactions and biochemical properties. The imidazoles are one of the most important substructures found in a large number of natural products and pharmacologically active compounds. For example, histidine, histamine and biotin, an active component in several drug molecules ${ }^{2}$, anti-allergic activity $^{3}$, hypnotic agent etomidate ${ }^{4}$, proton pump inhibitor omeprazole ${ }^{5}$ and the benzodiazepine antagonist flumazenil ${ }^{6}$ are imidazole derivatives. Recent advances in green chemistry and organometallic catalysis has extended the application of imidazoles as ionic liquids $^{7}$ and $N$-heterocyclic carbenes ${ }^{8}$. Also, tetrasubstituted imidazole scaffold is a core constituent in many biological systems such as olmesartan ${ }^{9}$ as well as many natural products and pharmacologically active compounds ${ }^{10}$. Therefore, the imidazole and its adjective structures are attractive compounds for organic chemists. 
Despite the availability of wide variety of synthetic routes towards imidazoles ${ }^{11}$, only few studies exist for the synthesis of 1,2,4,5-tetrasubstituted imidazoles. The mostly used methods in the last decades are as follows: $N$-alkylation of trisubstituted imidazoles ${ }^{12}$, condensation of $\beta$-carbonyl- $N$-acyl- $N$-alkylamines with ammonium acetate in refluxing $\mathrm{HOAc}^{13}$ and hetero-cope rearrangement ${ }^{14}$. Also, tetrasubstituted imidazoles can be prepared by four-component condensation of diones(such as benzil or benzoin), aldehydes, primary amines and ammonium acetate catalyzed by $\mathrm{HOAc}$ under reflux conditions ${ }^{15}$, silicagel $/ \mathrm{NaHSO}_{4}{ }^{16}$, silica gel or zeolite $\mathrm{HY}^{17}$, molecular iodine ${ }^{18}, \mathrm{InCl}_{3} \cdot 3 \mathrm{H}_{2} \mathrm{O}^{19}$, Keggintype heteropoly acids ${ }^{20}, \mathrm{~K}_{5} \mathrm{CoW}_{12} \mathrm{O}_{40} \cdot 3 \mathrm{H}_{2} \mathrm{O}^{21}$, high surface area $\mathrm{SiO}_{2}{ }^{22}$ and L-proline ${ }^{23}$. Recently, a solvent free convenient method has been reported using a silica-supported boron triflouride $\left(\mathrm{BF}_{3}-\mathrm{SiO}_{2}\right)$ as a catalyst at $140{ }^{\circ} \mathrm{C}^{24}$.

In the classic approach for the synthesis of tetrasubstituted imidazoles, four-component reaction proceeds with low yields after many hours in refluxing $\mathrm{HOAc}^{15}$. Other methods also use of hazardous, toxic, special and often expensive reagent or acid catalysts, long reaction time, occurrence of side reactions, moderate yield and were not suitable for, or were not applied for the synthesis of structurally diverse imidazoles. Therefore, the development of a new catalytic system to overcome these shortcomings and fulfill the criteria of a mild, clean, efficient, high-yielding, environmentally friendly and recoverable catalyst benign protocol for the synthesis of highly substituted imidazoles is an important task for organic chemists.

In the last decade, heteropoly acids (HPAs) have found numerous applications as useful and versatile as homogeneous and heterogeneous acid and oxidation catalysts. Heteropoly acids are more reactive catalysts than conventional inorganic and organic acids for reactions in solution $^{25}$. They are usually solids that are insoluble in non-polar solvents but highly soluble in polar ones. Heteropoly acids have many advantages finding economically and environmentally attractive in both academic and industrial significance. They are non-volatile, non-toxic, nonexplosive, highly stable towards humidity, thermally robust, air stable, recyclable, eco-friendly compatible with the environment, ease of handling and experimental simplicity ${ }^{26}$.

Preyssler structure $\left(\mathrm{H}_{14}\left[\mathrm{NaP}_{5} \mathrm{~W}_{30} \mathrm{O}_{110}\right]\right)$ is one member of the heteropoly acids group. A Preyssler acid is a highly acidic catalyst from heteropoly acid family with excellent catalytic activity in a variety of acid-catalyzed reactions ${ }^{27}$.

\section{Experimental}

All products are known compound, which were satisfactory characterized by physical and spectra data ${ }^{23,28}$ and the melting points and spectral data of products in this work is in full agreement with the reported literatures.

\section{General procedure}

\section{Preparation of tetrasubstituted imidazoles}

To a solution of benzyl $(1 \mathrm{mmol})$, amine $(1 \mathrm{mmol})$, aldehyde $(1 \mathrm{mmol})$ and ammonium acetate $(1 \mathrm{mmol})$ in ethanol $(10 \mathrm{~mL})$ was added Preyssler heteropoly acid $(1 \mathrm{~mol} \%)$. The mixture was heated with stirring at reflux temperature for 10-30 min. After completion of the reaction (the progress of the reaction was monitored by TLC), the mixture was cooled to room temperature and the precipitated products were separated by filtration; then washed with water and dried. The solid products were then recrystallized from ethanol to obtain the pure products. Also, the catalyst could be recycled after evaporation of solvent from the residue solution, washed with diethyl ether and dried. Physical and spectroscopic data of some 1,2,4,5-tetrasubstituted imidazoles are given below: 


\section{1-Benzyl-2,4,5-triphenyl-1H-imidazole(4a)}

M.p: $163-166{ }^{\circ} \mathrm{C} ;{ }^{1} \mathrm{H} \operatorname{NMR}\left(500 \mathrm{MHz}, \mathrm{CDCl}_{3}\right) \delta(\mathrm{ppm}): 5.15\left(\mathrm{~s}, 2 \mathrm{H}, \mathrm{CH}_{2}\right), 6.82-7.60(\mathrm{~m}, 20 \mathrm{H}$, $\mathrm{Ph})$; IR $(\mathrm{KBr})\left(v_{\max }, \mathrm{cm}^{-1}\right)$ : 3052, 2921, 1604; MS $(\mathrm{m} / z): 386\left(\mathrm{M}^{+}\right)$; Anal. Calcd. for $\mathrm{C}_{28} \mathrm{H}_{22} \mathrm{~N}_{2}$ : C, 87.01; H, 5.74; N, 7.25. Found: C, 87.11; H, 5.79; N, 7.40.

\section{1-Methyl-4,5-diphenyl-2-p-tolyl-1H-imidazole(4i)}

M.p: $222-225{ }^{\circ} \mathrm{C} ;{ }^{1} \mathrm{H}$ NMR(500 MHz, $\left.\mathrm{CDCl}_{3}\right) \delta(\mathrm{ppm}): 2.38\left(\mathrm{~s}, 3 \mathrm{H}, \mathrm{CH}_{3} \mathrm{Ph}\right), 3.63(\mathrm{~s}, 3 \mathrm{H}$, $\left.\mathrm{CH}_{3} \mathrm{~N}\right)$, 7.08-7.68(m, 14H, Ph); IR $(\mathrm{KBr})\left(v_{\max }, \mathrm{cm}^{-1}\right): 3061,2929,1635 ; \mathrm{MS}(\mathrm{m} / \mathrm{z})$ : 324 $\left(\mathrm{M}^{+}\right)$; Anal. Calcd. for $\mathrm{C}_{23} \mathrm{H}_{20} \mathrm{~N}_{2}$ : C, 85.15; H, 6.21; N, 8.63. Found: C, 85.21; H, 6.28; $\mathrm{N}, 8.50$.

\section{4-(1,4,5-Triphenyl-1H-imidazol-2-yl)phenol(4l)}

M.p: $279-282{ }^{\circ} \mathrm{C} ;{ }^{1} \mathrm{H} \operatorname{NMR}\left(500 \mathrm{MHz}, \mathrm{CDCl}_{3}\right) \delta(\mathrm{ppm}): 6.79-7.78(\mathrm{~m}, 19 \mathrm{H}, \mathrm{Ph}), 8.28(\mathrm{~s}, 1 \mathrm{H}$, $\mathrm{OH})$; IR (KBr) $\left(v_{\max }, \mathrm{cm}^{-1}\right): 3442,3059,1587$; MS $(\mathrm{m} / \mathrm{z}): 388\left(\mathrm{M}^{+}\right)$; Anal. Calcd. for $\mathrm{C}_{27} \mathrm{H}_{20} \mathrm{~N}_{2} \mathrm{O}$ : C, 83.48; H, 5.19; N, 7.21. Found: C, 83.55; H, 5.11; N, 7.29.

\section{Results and Discussion}

In continuation of our study ${ }^{27}$ in exploring application of heteropoly acids in fine organic chemistry, we have suggested this method for synthesis of 1,2,4,5tetrasubtituted imidazoles by using inexpensive and reusable Preyssler heteropoly acid catalyst in high yields (Scheme 1).

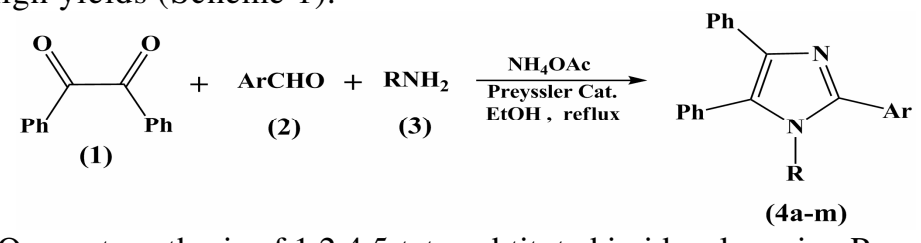

Scheme 1. One-pot synthesis of 1,2,4,5-tetrasubtituted imidazoles using Preyssler catalyst

To find simple and suitable conditions for synthesis of 1,2,4,5-tetrasubstituted imidazoles, the reaction of benzil (1), benzaldehyde (2a), benzyl amine (3a) and ammonium acetate was chosen as a model to form the 1-benzyl-2,4,5-triphenyl-1H-imidazole (4a) and reaction progress was studied under different conditions by thin layer chromatography (TLC).

A summary of obtained results have been shown in Table 1. Entries 1-4 in this table show the effect of various amounts of Preyssler acid catalyst on the rate and yield of the reaction. As is observable, if the amount of catalyst is two-fold from $0.5 \mathrm{~mol} \%$, amount of product increased perceptibly, but if also increase, amount of product increased very slowly. Then the best ratio of benzil, aldehyde, primary amine, $\mathrm{NH}_{4} \mathrm{OAc}$ and catalyst at mole is $1: 1: 1: 1: 0.01$.

Table 1. Effect of Preyssler acid catalyst amount

\begin{tabular}{|c|c|c|}
\hline Entry & Amount of catalyst, $\mathrm{mol} \%^{\mathrm{a}}$ & Yield, $\%^{\mathrm{b}}$ \\
\hline 1 & 0.5 & 48 \\
\hline 2 & 1 & 95 \\
\hline 3 & 2 & 97 \\
\hline 4 & 5 & 95 \\
\hline
\end{tabular}

${ }^{a}$ Reaction of benzyl 1 (1 mmol), benzaldehyde 2 a $(1 \mathrm{mmol})$, benzyl amine $3 \mathrm{a}(1 \mathrm{mmol})$ and ammonium acetate $(1 \mathrm{mmol})$ in presence of different amount of Preyssler acid catalyst. b) Isolated yield after 0.5 hour reflux 
Because of the mechanism of action for this catalyst in a solvent, we also studied the rate and yield of the reaction in different solvents such as water, dichloromethane, chloroform, acetonitrile and ethanol. Thus, among the tested solvents, ethanol was applied as acceptable solvent for this reaction. Also, the yield increased as the reaction temperature was raised. So, in other studies all reactions carried out in refluxing ethanol.

A comparative study with a few samples literature reported methods for this one-pot four-component reaction to synthesis 1,2,4,5-tetra subtituted imidazoles is compiled in Table 2 . As can be seen, our method is more efficient in time of reaction and amount of yield than other catalysts that reported (Table 2, entry 1-6).

Table 2. Comparison of different catalysts reported in literatures for one-pot synthesis of 1,2,4,5-tetrasubtituted imidazoles

\begin{tabular}{|c|c|c|c|c|}
\hline Entry & Catalyst & Conditions & Time & $\begin{array}{c}\text { Conversion, \% } \\
\text { [Ref.] }\end{array}$ \\
\hline 1 & $\mathrm{~K}_{5} \mathrm{CoW}_{12} \mathrm{O}_{40} \cdot 3 \mathrm{H}_{2} \mathrm{O}$ & $\mathrm{CH}_{2} \mathrm{Cl}_{2} /$ reflux & $2-2.5 \mathrm{~h}$ & $80-93^{[21]}$ \\
\hline 2 & silicagel/$/ \mathrm{NaHSO}_{4}$ & $\mathrm{CH}_{2} \mathrm{Cl}_{2} /$ reflux & $2 \mathrm{~h}$ & $85-92^{[16]}$ \\
\hline 3 & $\mathrm{InCl}_{3}-3 \mathrm{H}_{2} \mathrm{O}$ & $\mathrm{MeOH} /$ r.t. & $8-9.5 \mathrm{~h}$ & $69-82^{[19]}$ \\
\hline 4 & high surface $\mathrm{SiO}_{2}$ & $\mathrm{CH}_{2} \mathrm{Cl}_{2} /$ sunlight & $2-2.5 \mathrm{~h}$ & $84-93^{[22]}$ \\
\hline 5 & L-Proline & $\mathrm{MeOH} /$ reflux & $8.5-10 \mathrm{~h}$ & $78-88^{[23]}$ \\
\hline 6 & $\mathrm{H}_{14}\left[\mathrm{NaP}_{5} \mathrm{~W}_{30} \mathrm{O}_{110}\right]$ & EtOH/reflux & $10-30 \mathrm{~min}$ & 85-97, this work \\
\hline
\end{tabular}

The results of our work are presented in Table 3. As can be seen, aromatic aldehydes bearing both electron-donating and electron-withdrawing groups readily undergo the reaction giving excellent yields of corresponding to these reactions. Also, it should be noted that, this method is effective for the preparation of tetrasubstituted imidazoles from both aliphatic and aromatic amines. However, the catalytic system approximately works best for aromatic amines.

Table 3. Synthesis of 1,2,4,5-tetrasubstituted imidazoles using Preyssler acid as catalyst in refluxing ethanol

\begin{tabular}{|c|c|c|c|c|c|c|}
\hline Entry & $\mathrm{Ar}$ & $\mathrm{R}$ & Product & $\begin{array}{l}\text { Time, } \\
\min \end{array}$ & $\begin{array}{c}\text { Yield } \\
\%\end{array}$ & $\begin{array}{c}\text { M.P., }{ }^{\circ} \mathrm{C} \\
\text { Found/Reported[Ref] }\end{array}$ \\
\hline 1 & $\mathrm{C}_{6} \mathrm{H}_{5}$ & $\mathrm{PhCH}_{2}$ & $4 \mathbf{a}$ & 10 & 95 & $163-166 / 165-167^{[24]}$ \\
\hline 2 & $4-\mathrm{Cl}-\mathrm{C}_{6} \mathrm{H}_{4}$ & $\mathrm{PhCH}_{2}$ & $4 b$ & 20 & 88 & $163-165 / 162-165^{[24]}$ \\
\hline 3 & $4-\mathrm{CH}_{3} \mathrm{O}-\mathrm{C}_{6} \mathrm{H}_{4}$ & $\mathrm{PhCH}_{2}$ & $4 c$ & 20 & 97 & $159-162 / 157-160^{[24]}$ \\
\hline 4 & $4-\mathrm{CH}_{3}-\mathrm{C}_{6} \mathrm{H}_{4}$ & $\mathrm{PhCH}_{2}$ & 4d & 20 & 92 & $161-164 / 165-168^{[24]}$ \\
\hline 5 & $4-\mathrm{OH}-\mathrm{C}_{6} \mathrm{H}_{4}$ & $\mathrm{PhCH}_{2}$ & $4 e$ & 10 & 93 & $134-137 / 134-136^{[24]}$ \\
\hline 6 & $2-\mathrm{OH}-\mathrm{C}_{6} \mathrm{H}_{4}$ & $\mathrm{PhCH}_{2}$ & $4 f$ & 30 & 88 & $145-148 / 147-148^{[24]}$ \\
\hline 7 & $4-\mathrm{Br}-\mathrm{C}_{6} \mathrm{H}_{4}$ & $\mathrm{PhCH}_{2}$ & $4 g$ & 20 & 85 & $168-171 / 170-172^{[24]}$ \\
\hline 8 & $\mathrm{C}_{6} \mathrm{H}_{5}$ & $\mathrm{CH}_{3}$ & $4 h$ & 30 & 86 & $142-145 / 144-145^{[23]}$ \\
\hline 9 & $4-\mathrm{CH}_{3}-\mathrm{C}_{6} \mathrm{H}_{4}$ & $\mathrm{CH}_{3}$ & $4 i$ & 20 & 85 & $222-225 / 221-223^{[23]}$ \\
\hline 10 & $4-\mathrm{Br}-\mathrm{C}_{6} \mathrm{H}_{4}$ & $\mathrm{CH}_{3}$ & $4 j$ & 20 & 85 & $202-205 / 201-203^{[23]}$ \\
\hline 11 & $4-\mathrm{CH}_{3}-\mathrm{C}_{6} \mathrm{H}_{4}$ & $\mathrm{Ph}$ & $4 \mathbf{k}$ & 30 & 89 & $189-191 / 187-189\left[^{28]}\right.$ \\
\hline 12 & 4-OH- $\mathrm{C}_{6} \mathrm{H}_{4}$ & $\mathrm{Ph}$ & 41 & & 91 & $279-282 / 284-286^{[28]}$ \\
\hline 13 & $4-\mathrm{NO}_{2}-\mathrm{C}_{6} \mathrm{H}_{4}$ & $\mathrm{Ph}$ & $4 m$ & & 87 & $192-195 / 191-193^{[28]}$ \\
\hline
\end{tabular}

It should be mentioned that the products of this reaction could be easily separated from catalyst. Preyssler heteropoly acid is soluble in ethanol at room temperature but the products are not. So, finally reaction when the mixture cooled to room temperature, the products were insoluble and could be separated by a simple filtration. $\mathrm{H}_{14}\left[\mathrm{NaP}_{5} \mathrm{~W}_{30} \mathrm{O}_{110}\right]$ catalyst was also found to be reusable several times. However, little reduction in activity of catalyst was observed (Table 4). 
Table 4. Investigation of the feasibility of reusing Preyssler acid catalyst in synthesis of 1-benzyl-2,4,5-triphenyl-1 $H$-imidazole (4a) in ethanol

\begin{tabular}{ccccc}
\hline Run $^{\text {a }}$ & 1 & 2 & 3 & 4 \\
\hline Yield, \% & 95 & 91 & 83 & 65 \\
\hline
\end{tabular}

${ }^{a}$ Catalyst could be recycled: the product filtered off, the solvent was evaporated and the remained catalyst was washed with diethyl ether and dried at $100^{\circ} \mathrm{C}$ for $1 \mathrm{~h}$

\section{Conclusion}

Preyssler-type heteropoly acid $\mathrm{H}_{14}\left[\mathrm{NaP}_{5} \mathrm{~W}_{30} \mathrm{O}_{110}\right]$ is a highly efficient solid acid catalyst for the synthesis of 1,2,4,5-tetrasubstituted imidazoles. Excellent yields, enhanced reaction rates and short reaction times, compatibility with various functional groups, simplicity of operation and easy work-up are some advantages of this protocol. Also, preyssler is a gettable, cheap, stable, reusable and agreeable with environment catalyst. Hence, we believe that this method will find wide application in organic synthesis as well as industry.

\section{References}

1. Debus H, Liebigs Ann Chem., 1858, 107, 199.

2. Abrahams S L, Hazen R J, Batson A G and Phillips A P J Pharmacol Exp Ther., 1989, 249(2), 359-365.

3. Black J W, Durant G J, Emmett J C and Ganellin C R, Nature, 1974, 248, 65-67.

4. Wauquier A, Van Den Broeck W A E, Verheyen J L and Janssen P A J, Eur J Pharmacol., 1978, 47, 367-377.

5. Tanigawara Y, Aoyama N, Kita T, Shirakawa K, Komada F, Kasuga M and Okumura K, Clin Pharmacol Ther., 1999, 66, 528-534.

6. Hunkeler W, Mohler H, Pieri L, Polc P, Bonetti E P and Cumin R, Schaffner R and Haefely W, Nature, 1981, 290, 514-516.

7. (a) Wasserscheid P and Keim W, Angew Chem Int Ed Eng., 2000, 39, 3772-3789;

(b) Chowdhury S, Mohan R S and Scott J L, Tetrahedron, 2007, 63, 2363.

8. (a) Bourissou D, Guerret O, Gabbai F P and Bertrand G, Chem Rev., 2000, 100, 39-92;

(b) Arnold P L and Liddle S T, Chem Commun., 2006, 3959-3971; (c) Kuhl O, Chem Soc Rev., 2007, 36, 592-607.

9. Wolkenberg S E, Wisnoski D D, Leister W H, Wang Y, Zhao Z and Lindsley C W, Org Lett., 2004, 6, 1453-1456.

10. (a) Sisko J, J Org Chem., 1998, 63, 4529-4531; (b) Shilcrat S C, Mokhallalati M K, Fortunak J M D and Pridgen L N, J Org Chem., 1997, 62, 8449-8454.

11. Gribble G W, Joule J A and Gilchrist T L, Progress in Heterocyclic Chemistry, Elsvier, Oxford, 2001-2005, 13-17.

12. Davidson D, Weiss M and Jelling M, J Org Chem., 1937, 2, 319.

13. Evans D A and Lundy K M, J Am Chem Soc., 1992, 114, 1495-1496.

14. Lantos I, Zhang W Y, Shui X and Eggleston D S, J Org Chem., 1993, 58, 7092.

15. Schubert H and Stodolka H, J Prakt Chem., 1963, 22, 130-133.

16. Karimi A R, Alimohammadi Z, Azizan J, Mohammadi A A and Mohmmadizadeh R R, Catal Commun., 2006, 7, 728.

17. Balalaei S and Arabanian A, Green Chem., 2000, 2, 274-276.

18. Kidwai M, Mothsro P, Bansal V, Somvanshi R K, Ethayathulla A S, Dey S and Singh T P, J Mol Catal A: Chem., 2007, 265, 177.

19. Sharma S D, Hazarika P and Konwar D, Tetrahedron Lett., 2008, 49, 2216-2220. 
20. Heravi M M, Derikvand F and Bamoharram F F, J Mol Catal A: Chem., 2007, 263, 112-114.

21. Nagarapu L, Apuri S and Kantevari S, J Mol Catal A: Chem., 2007, 266, 104-108.

22. Mekheimer R A, Abdel Hameed A M, Mansour S A A and Sadek K U, Chin Chem Lett., 2009, 20, 812.

23. Samai S, Nandi G C, Singh P and Singh M S, Tetrahedron, 2009, 65, 10155.

24. Sadeghi B, Mirjalili B F and Hashemi M M, Tetrahedron Lett., 2008, 49, 2575.

25. (a) Kozhevnikov I V, Chem Rev., 1998, 98, 171-198; (b) Mizuno N and Misono M, Chem Rev., 1998, 98, 199.

26. Heravi M M and Sadjadi S, J Iran Chem Soc., 2009, 6, 1.

27. (a) Bamoharram F F, Heravi M M and Meraji M, Int J Green Nanotechnol Phys Chem., 2009, 1, 26-31; (b) Bamoharram F F, Heravi M M, Roushani M, Toosi M R and Jodeyre L, Green Chem Lett Rev., 2009, 2(1), 35-41; (c) Heravi M M, Sadjadi S, Oskooie H A, Hekmat Shoar R and Bamoharram F F, Catal Commun., 2008, 9, 470; (d) Heravi M M, Sadjadi S, Oskooie H A, Hekmat Shoar R and Bamoharram F F, Catal Commun., 2008, 9, 504; (e) Hekmat Shoar R, Heravi M M, Sadjadi S, Oskooie H A and Bamoharram F F, Catal Commun., 2008, 9, 837-841; (f) Heravi M M, Zadsirjan V, Bakhtiari K, Oskooie H A and Bamoharram F F, Catal Commun., 2007, 8(3), 315-318; (g) Heravi M M, Khorasani M, Derikvand F, Oskooie H A and Bamoharram F F, Catal Commun., 2007, 8, 1886; (h) Heravi M M, Bakhtiari K, Zadsirjan V and Bamoharram F F, Bioorg Med Chem Lett., 2007, 17, 4262-4265.

28. Ucucu U, Karaburun N G and Isikdag I, Il Farmaco., 2001, 56, 285-290. 


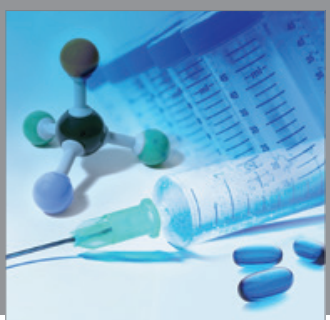

International Journal of

Medicinal Chemistry

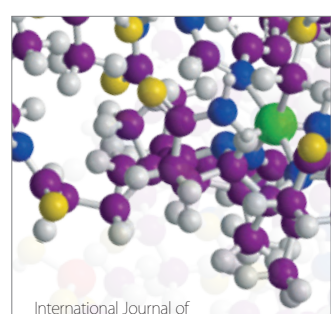

Carbohydrate Chemistry

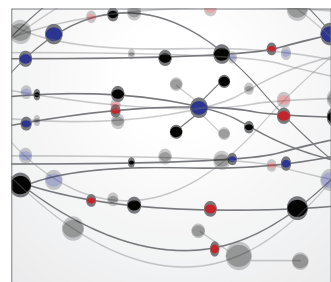

The Scientific World Journal
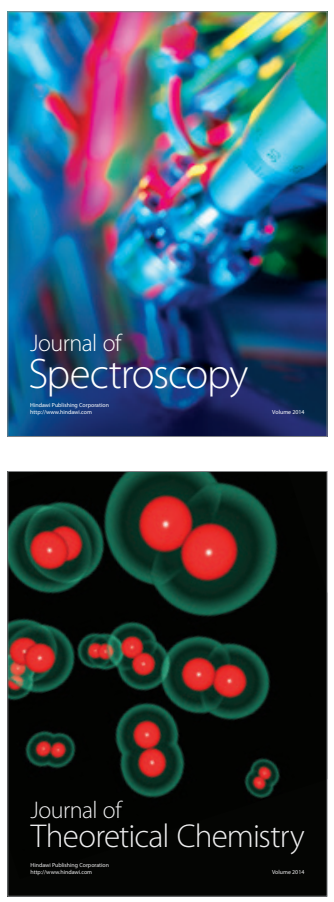
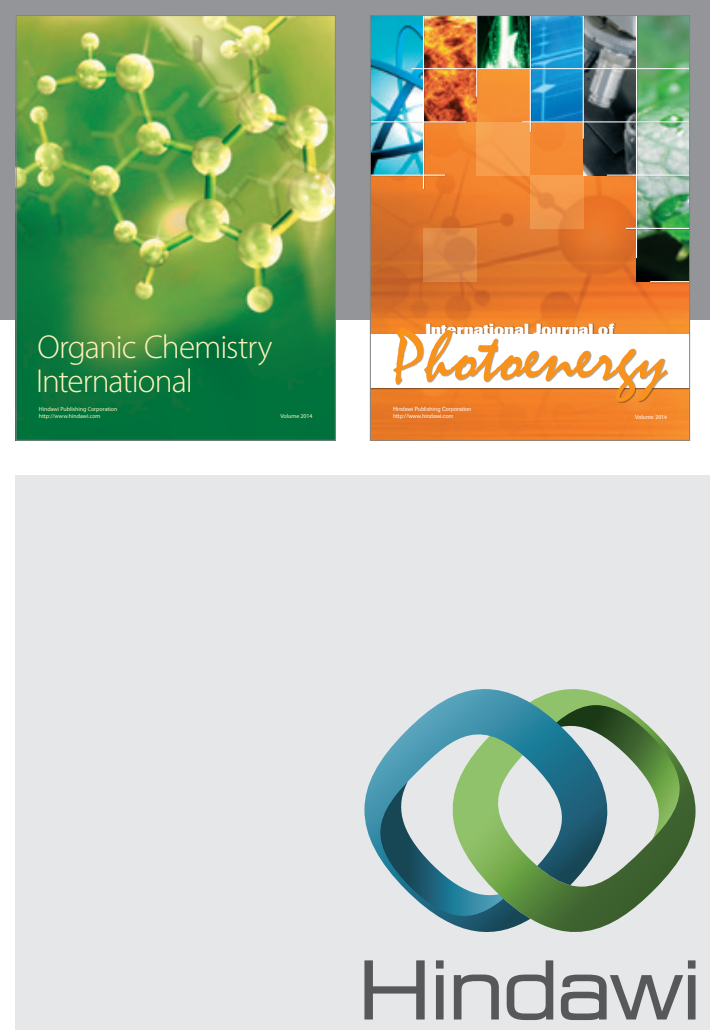

Submit your manuscripts at

http://www.hindawi.com
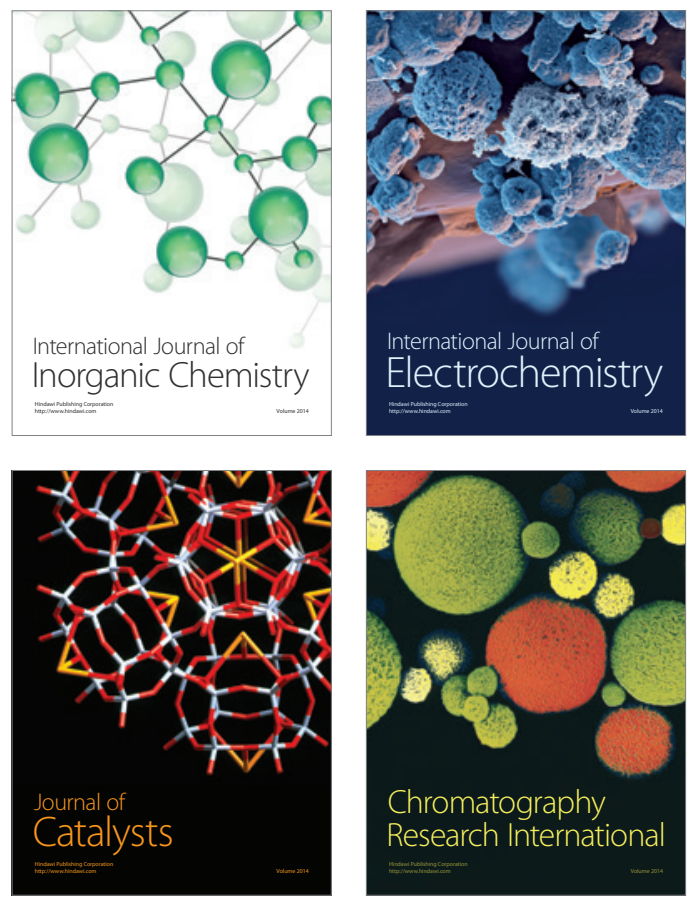
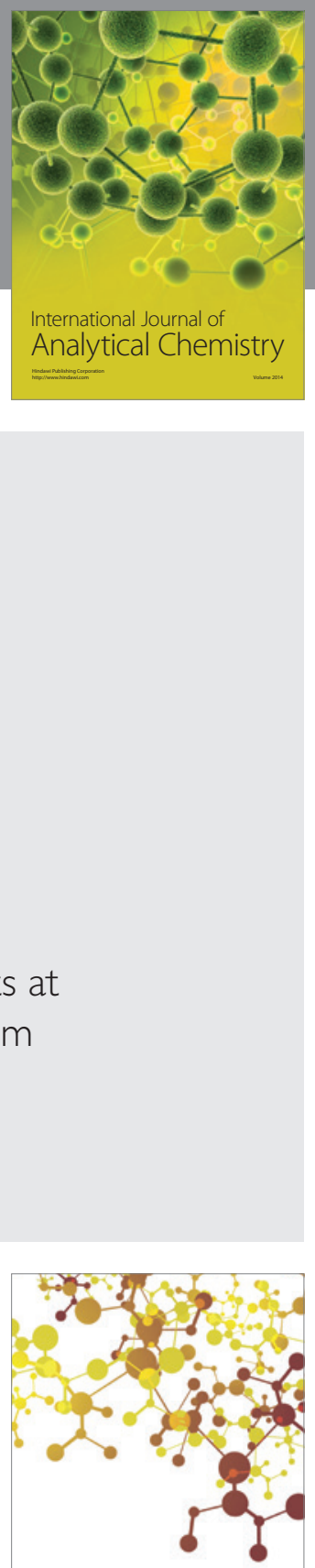

Journal of

Applied Chemistry
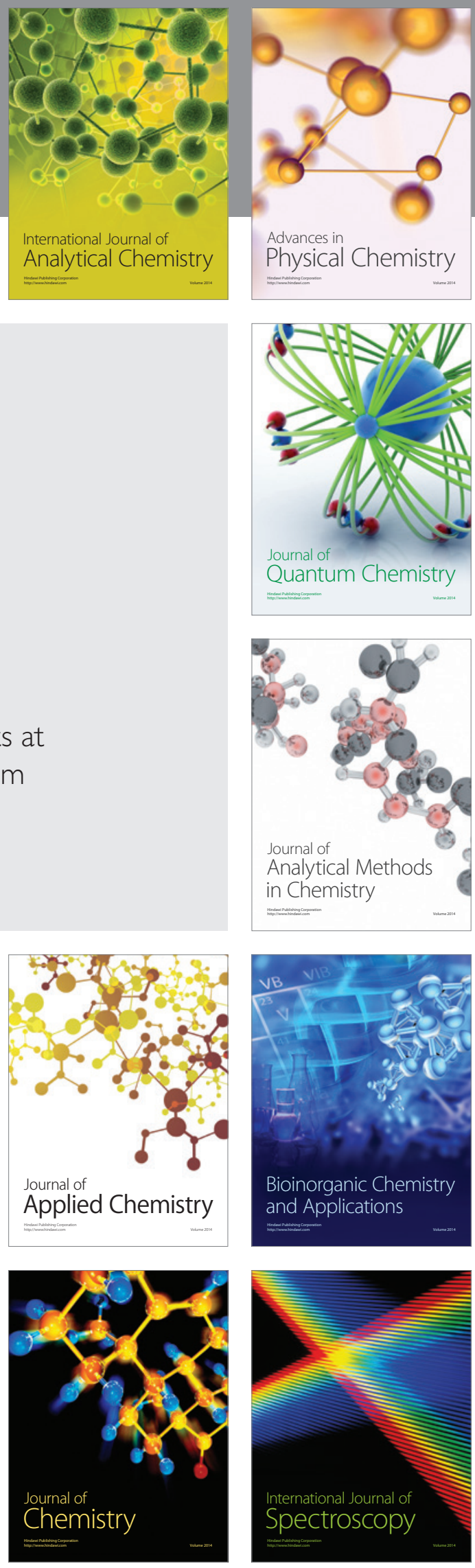